\title{
PENGARUH MODEL PEMBELAJARAN KONTEKSTUAL PADA POKOK BAHASAN HIDROKARBON TERHADAP HASIL BELAJAR KIMIA
}

\author{
Diah Artini, Nyoman Suardana, Made Wiratini \\ Universitas Pendidikan Ganesha \\ Email: ayudiahartini08@gmail.com
}

\begin{abstract}
ABSTRAK
Penelitian ini bertujuan mendeskripsikan pengaruh model pembelajaran kontekstual pada pokok bahasan hidrokarbon terhadap hasil belajar kimia siswa. Penelitian ini merupakan eksperimen semu dengan rancangan nonequivalent pre-test post-test control group design. Populasi penelitian ini adalah seluruh siswa kelas XI MIPA SMA Negeri 1 Penebel tahun ajaran 2018/2019. Sampel penelitian ini adalah siswa kelas XI MIPA 1 sebagai kelas eksperimendan siswa kelas XI MIPA 2 sebagai kelas kontrol yang dipilih dengan teknik cluster random sampling. Siswa di kelas eksperimen dibelajarkan dengan model pembelajaran kontekstual dan siswa di kelas kontrol dibelajarkan dengan model pembelajaran discovery. Data hasil belajar kimia siswa dikumpulkan dengan cara testing menggunakan tes hasil belajar. Data dianalisis dengan teknik analisis deskriptif dan inferensial. Analisis deskriptif hasil belajar kimia siswa dideskripsikan berupa skor ratarata pre-test dan post-test siswa. Analisis inferensial hasil belajar kimia siswa menggunakan analisis kovarian (Anakova) dengan taraf signifikansi 0.05 dan uji dilakukan dengan bantuan SPSS 16 for windows. Hasil analisis menunjukkan terdapat pengaruh signifikan model pembelajaran kontekstual terhadap hasil belajar kimia siswa. Skor rata-rata hasil belajar siswa di kelas eksperimen (73.42) lebih tinggi dibandingkan dengan kelas kontrol (64.26).
\end{abstract}

Katakunci: model pembelajaran kontekstual, model pembelajaran discovery, hasil belajar kimia

\begin{abstract}
This reseach aim to describe the influence of the contextual learning model to chemistry student's achievement. It is a quasi-experiment reseach with nonequivalent pre-test posttest control group design. The population was the eleventh-grade student's of SMA Negeri 1 Penebelon academic year 2018/2019. The samples werethe students of XI MIPA 1 class as experimental class and the students of XI MIPA 2 class as control class that selected with cluster random sampling technique. The students in the experimental class learned through the contextual learning model and the ones in the control class learned through the discovery learning model. The data on the chemistry student's achievement were collected through the test of the achievement test. The data were analyzed through descriptive and inferential analysis. Descriptive analysisof chemistry student's achievement were described in the form of the mean score of student's pre-test and post-test. Inferential analysis of chemistry student's achievement were used covarian analysis (Anacova) with 0.05 significance level and it was performed by the assist of SPSS 16 for windows. The results showed that there were the significant effect of
\end{abstract}


contextual learning model to the chemistry student's achievement. The mean score of student's achievement in experimental class (73.42) was higher than control class (64.26).

Keywords: contextual learning model, discovery learning model, chemistry student's achievement

\section{PENDAHULUAN}

Kemajuan suatu bangsa sangat ditentukan oleh pendidikan. Pendidikan yang tertata dengan baik dapat menciptakan generasi yang berkualitas. Salah satu upaya pemerintahan dalam meningkatkan kualitas pendidikan adalah pengembangan kurikulum 2013. Kurikulum ini mengharapkan proses pembelajaran yang dilaksanakan menekankan pada penggunaan pendekatan saintifik.

Berdasarkan Permendikbud Nomor 81a Tahun 2013 tentang implementasi kurikulumditegaskan bahwa proses pembelajaran pada kurikulum 2013 dilaksanakan dengan menggunakan pendekatan saintifik. Proses pembelajaran ini menekankan pada keterlibatan siswa selama proses pembelajaran atau proses pembelajaran yang berpusat pada siswa (student centered).

Pelaksanaan pembelajaran kimia di sekolah diharapkan menggunakan pendekatan saintifik sesuai dengan kurikulum 2013. Berdasarkan Permendikbud No 103 Tahun 2014, kurikulum 2013 menggunakan tiga model pembelajaran utama yang diharapkan dapat membentuk perilaku saintifk, perilaku sosial, serta mengembangkan rasa keingintahuan. Ketiga model pembelajaran tersebut adalah model pembelajaran berbasis masalah (problem based learning), model pembelajaran berbasis projek (project based learning), dan model pembelajaran penyingkapan/penemuan (discovery/inquiry).

Berdasarkan hasil wawancara dengan seorang gurub kimia di SMA Negei 1 Penebel diperoleh bahwa sekolah tersebut menerapkan model pembelajaran discovery namun pelaksanaan model tersebut belum berlangsung optimal karena pada saat proses pembelajaran siswa masih cenderung kurang aktif. Model pembelajaran discoveryadalah model pembelajaran yang mengharapkan siswa mengorganisasi pengetahuannya. Model pembelajaran discovery adalah memahami konsep, arti, dan hubungan, melalui suatu proses untuk akhirnya sampai pada suatu kesimpulan (Budiningsih, 2005). Kreativitas siswa mempunyai pengaruh yang cukup besar dengan menggunakan model pembelajaran discovery. Siswa yang memiliki kreativitas yang rendah akan mengalami kesulitan dalam proses pembelajaran menggunakan model pembelajaran discovery. Hal ini menyebabkan siswa yang memiliki tingkat kreativitas rendah mengalami kesulitan dalam memecahkan masalah terutama berkaitan dengan fenomena alam atau kehidupan sehari-hari dan bersifat abstrak serta hasil belajar siswa menjadi rendah (Agustina, 2016). Hasil belajar kimia siswa yang ditemukan masih rendah karena rendahnya keterlibatan siswa selama proses pembelajaran (Perdana, 2014; Suryanto, 2015). Hasil belajar kimia siswa yang rendah juga ditemukan pada topik hidrokarbon (Ardiansyah, 2013; Wartini, 2014).

Hidrokarbon merupakan dasar materi kimia yang erat kaitannya dengan kehidupan sehari-hari, yang berguna untuk mempelajari konsep-konsep kimia lebih lanjut. Namun konsep hidrokarbon sangat luas, bersifat abstrak, dan memiliki jalinan antar, sehingga dalam mempelajarinya perlu berkesinambungan. Hal ini menyebabkan konsep hidrokarbon sulit dipahami siswa. Oleh karena itu, dalam mempelajari materi hidrokarbon diperlukan model pembelajaran yang baik dan tepat, agar siswa termotivasi.

Berdasarkan temuan tersebut, perlu diterapkan suatu proses pembelajaran yang tepat dengan materi pembelajaran yang akan dibahas sehingga hasil belajar yang optimal akan tercapai. Salah satu model pembelajaran inovatif yang dapat memenuhi tuntutan kurikulum 2013 dan sesuai dengan karakteristik materi hidrokarbon adalah model pembelajaran kontekstual. Model ini dipilih karena model ini digunakan bagi siswa yang sulit memahami konsep yang abstrak dan belum berpengalaman dalam pembelajaran yang inkuiri sehingga masih diperlukan bimbingan dari guru.

Model pembelajaran kontekstual adalah model pembelajaran yang menghadirkan konteks atau contoh nyata yang berhubungan dengan materi yang dipelajari. Menurut Rusman (2012) bahwa model pembelajaran kontekstual merupakan konsep belajar yang dapat membantu guru mengaitkan antara materi yang diajarkan dan situasi dunia nyata siswa dan mendorong siswa membuat hubungan antara pengetahuan yang dimiliki siswa dan penerapan dalam kehidupan mereka. Pada penyampaian 
materi, konteks atau contoh yang dipilih harus sesuai dengan kehidupan sehari-hari dan tingkatan kognitif siswa. Oleh karena itu, pemilihan contoh yang sesuai dapat membantu siswa untuk berpikir dan mempertanggung jawabkan gagasan atau pendapatnya tersebut siswa menjadi lebih aktif terlibat dalam diskusi sehingga semakin percaya diri untuk menyampaikan pendapat serta bertanya tentang hal-hal yang berhubungan dengan materi yang dipelajari. Sabil (2011) mengatakan bahwa setelah mengalami pembelajaran dengan model pembelajaran kontekstual siswa memiliki partisipasi aktif dalam berdiskusi, sehingga siswa berani untuk bertanya dan menyampaikan pendapatnya. Beberapa hasil penelitian tentang pembelajaran kontekstual yang telah dilakukan menunjukkan hasil bahwa penerapan model pembelajaran kontekstual dapat meningkatkan hasil belajar siswa.Hasil belajar yang diperoleh pada penelitian tersebut rata-rata 76 (Maharanimerta, 2013; Silaban, 2015; Nurhidayat, 2016).Berdasarkan uraian tersebut, untuk mengetahui konsistensi hasil penelitian tersebut, perlu dilakukan penelitian tentang pengaruh model pembelajaran inkuiri terbimbing terhadap hasil belajar kimia siswa.

\section{METODE}

Penelitian ini termasuk eksperimen semu (quasi eksperiment), yang menggunakan satu kelas sebagai kontrol dan satu kelas sebagai eksperimen dengan rancangan nonequivalent pre-test posttest control group design yang disajikan pada Tabel 01.

Tabel 01.Rancangan Penelitian

\begin{tabular}{lccc}
\hline Kelompok & Keadaanawal & Perlakuan & Keadaanakhir \\
\hline Eksperimen & $\mathrm{O}_{1}$ & $\mathrm{X}_{1}$ & $\mathrm{O}_{2}$ \\
Kontrol & $\mathrm{O}_{3}$ & $\mathrm{X}_{2}$ & $\mathrm{O}_{4}$ \\
\hline
\end{tabular}

Keterangan:

$\mathrm{X}_{1}=$ Pembelajaran dengan model Kontekstual

$\mathrm{X}_{2}=$ Pembelajaran dengan model Discovery

$\mathrm{O}_{1}, \mathrm{O}_{3}=$ Observasi pretes kelompok Eksperimen dan Kontrol

$\mathrm{O}_{2}, \mathrm{O}_{4}=$ Observasi postes kelompok Eksperimen dan Kontrol

Populasi penelitian ini adalah seluruh siswa kelas XI MIPA di SMA Negeri 1 Penebel yang berjumlah 96 siswa yang terdiri atas 3 kelas XI MIPA yang tidak dibedakan berdasarkan ranking. Sampelterpilih adalah kelas XI MIPA 2 sebagai kelas kontrol (31 siswa) dan kelas XI MIPA 1 sebagai kelas eksperimen (31 siswa) yang dipilih menggunakan teknik cluster random sampling.

Data yang dikumpulkan adalah hasil belajar kimia siswa (skorpretest dan postest siswa pada kelas kontrol dan eksperimen), yang dikumpulkan dengan cara testing menggunakan tes hasil belajar yang berupa soal pilihan ganda.

Tes pilihan ganda berjumlah 25 soal dengan karakteristik soal valid dengan rentangan nilai rbis yang diperoleh sebesar $0,23-0,71$. Soal memiliki reliabilitas tinggi dengan nilai reliabilitas sebesar 0,83 . Tingkat kesukaran soal meliputi 3 butir soal tergolong sangat mudah, 11 tergolong mudah, 10 tergolong sedang, dan 1 tergolong sukar. Daya beda soal meliputi 15 butir soal tergolong sedang, 4tergolong baik, dan 6 tergolong baik sekali.

Teknik analisis data yang digunakan pada penelitian ini meliputi analisis statistik deskriptif dan analisis statistik inferensial.Analisis deskriptif digunakan untuk mendeskripsikan data hasil belajar kimia siswa. Skor hasil belajar siswa dideskripsikan berdasarkan skor rata-rata, standar deviasi, skor maksimal, dan skor minimal pre-test dan post-test siswa. Analisis statistik inferensial yang digunakan untuk menganalisis skor hasil belajar adalah analisis kovarian (Anakova) dengan taraf signifikansi 0.05 dilakukan dengan bantuanSPSS 16 for windows. Uji prasyarat yang dilakukan sebelum analisis data adalah 1) Uji normalitas data dengan Kolmogorov-Smirnov Test dan/atauShapiro-Wilk, 2) Uji homogenitas varians dengan Levene's Test, 3) Uji linearitas dan keberartian regresi dengan statistic Test of Linierity, dan 4) Uji homogenitas kemiringan garis regresi menggunakan Analysis of Variance 
HASIL DAN PEMBAHASAN

Data skor pre-test danpost-testyang diperolehsiswa disajikan pada Tabel 02.

Tabel 02. Skor Pre-test dan Post-test Siswa Kelas Kontrol dan Kelas Eksperimen

\begin{tabular}{lllll}
\hline \multirow{1}{*}{ Statistik } & \multicolumn{3}{c}{ Pre-test } & Post-test \\
\cline { 2 - 5 } & Kontrol & Eksperimen & Kontrol & Eksperimen \\
\hline Rata-rata & $\mathbf{1 9 . 4 8}$ & $\mathbf{1 9 . 8 7}$ & $\mathbf{6 4 . 2 6}$ & $\mathbf{7 3 . 4 2}$ \\
SD & 9.89 & 9.77 & 14.64 & 14.22 \\
Skor Maks. & 36 & 36 & 88 & 96 \\
Skor Min & 4 & 4 & 40 & 48 \\
\hline
\end{tabular}

Berdasarkan Tabel 02,diketahui bahwa skor rata-rata pre-test siswa di kelas kontrol dan kelas eksperimen tidak jauh berbeda, hal ini berarti pemahaman awal siswa di kelas kontrol dan kelas ekperimen tidak jauh berbeda, sedangkan perbedaan skor post-test kelas eksperimen dan kelas kontrol cukup besar. Hal ini menunjukkan bahwa hasil belajar siswa di kelas eksperimen lebih baik dibandingkan hasil belajar siswa di kelas kontrol.

Berdasarkan nilai standar deviasi diketahui bahwa sebaran skor pre-test pada kelas kontrol lebih beragam dibandingkan sebaran skor pre-test pada kelas eksperimen dan sebaran skor post-test pada kelas kontrol lebih beragam dibandingkan sebaran skor post-test pada kelas eksperimen

Data skor pre-test dan post-test yang diperoleh siswa kemudian dikelompokkan ke dalam 5 kategori, yakni kategori sangat tinggi, tinggi, cukup, rendah, dan sangat rendah. Data skor pre-test dan post-test yang diperoleh dikategorikan dengan penilaian acuan patokan (PAP). Hasil pengelompokan disajikan pada Tabel 03.

Tabel03.KategoriPenggolongan Data Pre-test dan Post-test Siswa

\begin{tabular}{llcccc}
\hline \multirow{2}{*}{ Interval } & \multirow{2}{*}{ Kriteria } & \multicolumn{2}{c}{ Kelas Eksperimen } & \multicolumn{2}{c}{ Kelas Kontrol } \\
\cline { 3 - 6 } & & $\begin{array}{l}\text { Frekuensi } \\
\text { pre-test } \\
(\%)\end{array}$ & $\begin{array}{c}\text { Frekuensi } \\
\text { post-test } \\
(\%)\end{array}$ & $\begin{array}{c}\text { Frekuensi } \\
\text { pre-test } \\
(\%)\end{array}$ & $\begin{array}{c}\text { Frekuensi } \\
\text { post-test } \\
(\%)\end{array}$ \\
\hline $85-100$ & Sangat tinggi & 0 & 22.58 & 0 & 6.45 \\
$70-84$ & Tinggi & 0 & 38.71 & 0 & 32.26 \\
$55-69$ & Cukup & 0 & 25.81 & 0 & 32.26 \\
$40-54$ & Rendah & 0 & 12.90 & 0 & 29.03 \\
$<39$ & Sangat rendah & 100 & 0 & 100 & 0 \\
\hline & Jumlah & 100 & 100 & 100 & 100 \\
\hline
\end{tabular}

Berdasarkan Tabel 03, diketahui bahwa persentase frekuensi pre-test siswa di kelas eksperimen dan di kelas kontrol cenderung berada pada kategori rendah. Persentase frekuensi posttest siswa pada kelas eksperimen cenderung berada pada kategori tinggi sedangkan persentase frekuensi post-test siswa pada kelas kontrol cenderung berada pada kategori tinggi dan cukup.

Mengetahui tingkat signifikansi dengan analisis kovarian (Anakova), terlebih dahulu dilakukan uji prasyarat analisis.Berdasarkan hasil uji prasyarat tersebut diketahui bahwa data pada kelas kontrol dan kelas eksperimen berdistribusi normal, homogen, hubungan antara pemahaman awal (kovariat) dan hasil belajar siswa adalah linear dan berarti atau signifikan, serta variabel kovariat dinyatakan tidak berpengaruh secara signifikan terhadap hasil belajar, sehingga jika terdapat perbedaan hasil belajar siswa di kelas kontrol dan di kelas eksperimen disebabkan oleh perbedaan perlakuan yang diberikan dan tidak dipengaruhi oleh pemahaman awal siswa.

Berdasarkan uji prasyarat yang telah dilakukan, data yang diperoleh telah memenuhi persyaratan untuk dilakukan uji Anakova. Hasil uji hipotesis dapat dilihat pada Tabel 05. 
Vol. 3, No. 1, 2019

Tabel 05. Hasil Uji Hipotesis

\begin{tabular}{lrrrrr}
\hline Source & $\begin{array}{c}\text { Type III Sum } \\
\text { of Squares }\end{array}$ & df & Mean Square & F & Sig. \\
\hline Corrected Model & $13219.628^{\mathrm{a}}$ & 2 & 6609.814 & 676.156 & 0.000 \\
Intercept & 19912.959 & 1 & 19912.959 & $2.037 \mathrm{E} 3$ & 0.000 \\
Pretest & 11918.725 & 1 & 11918.725 & $1.219 \mathrm{E} 3$ & 0.000 \\
Model & 1147.613 & 1 & 1147.613 & 117.396 & $\mathbf{0 . 0 0 0}$ \\
Error & 576.759 & 59 & 9.776 & & \\
Total & 307600.000 & 62 & & & \\
Corrected Total & 13796.387 & 61 & & & \\
\hline
\end{tabular}

Berdasarkan Tabel 05,diketahui adanya pengaruh variabel independent (variabel bebas) terhadap variabel dependent (variabel terikat).

\section{PEMBAHASAN}

Berdasarkan hasil uji hipotesis yang telah dilakukan, dapat diambil kesimpulan bahwa terdapat pengaruh model pembelajaran kontekstual terhadap hasil belajar kimia siswa. Skor rata-rata pre-test siswa yang belajar dengan menggunakan model pembelajaran discovery dan siswa yang dibelajarkan dengan model pembelajaran kontekstual menunjukkan hasil yang tidak jauh berbeda, hal ini menunjukkan bahwa pemahaman awal siswa di kelas kontrol dan di kelas eksperimen tidak jauh berbeda.Pengujian hipotesis tidak dipengaruhi oleh perbedaan hasil pre-test disebabkan pengendalian variabel kovariat oleh anakova sehingga perbedaan hasil belajar yang terjadi memang karena perbedaan perlakukan yang diberikan.

Skor rata-rata post-test siswa yang belajar dengan menggunakan model pembelajaran discovery lebih rendah dibandingkan dengan siswa yang dibelajarkan dengan model pembelajaran kontekstual. Hal ini berarti siswa yang dibelajarkan dengan model pembelajaran kontekstual memiliki hasil belajar yang lebih baik dibandingkan siswa yang dibelajarkan dengan model pembelajaran discovery. Hasil analisis juga menunjukkan bahwa penggunaan model pembelajaran kontekstual efektif meningkatkan hasil belajar siswa. Hasil penelitian yang sejalan juga ditemukan oleh beberapa peneliti (Elvinawati, 2008; Maharani, 2013; Silaban, 2015; Hidayat, 2016; Khutni, 2017).

Tahapan pada proses pembelajaran kontekstual memberikan kesempatan kepada siswa untuk terlibat selama proses pembelajaran dan membantu siswa dengan menghadirkan konteks atau contoh nyata berupa suatu fenomena pada lembar kerja siswa (LKS) dan sebuah pemodelan yang berhubungan dengan materi yang dipelajari. Hal ini bertujuan untuk mengidentifikasi pengetahuan awal siswa yang bisa dipeoleh dari kehidupan sehari-hari siswa yang berkaitan dengan matei yang dipelajari. Hal ini sejalan dengan yang diungkapkan Nurhadi (dalam Rusman, 2012) bahwa model pembelajaran kontekstual merupakan konsep belajar yang dapat membantu guru mengaitkan antara materi yang diajarkan dan situasi dunia nyata siswa dan mendorong siswa membuat hubungan antara pengetahuan yang dimilikinya dan penerapan dalam kehidupan mereka. Pada tahap pemodelan ini, selain menghadirkan konteks atau contoh nyata yang berupa fenomena juga menghadirkan suatu model/contoh agar siswa lebih terarah untuk mengidentifikasi masalah yang terdapat dalam sebuah fenomena pada lembar kerja siswa (LKS). Menurut Sugiyanto (2008), pemodelan merupakan konsep belajar yang memberikan contoh kepada siswa dalam proses pembelajaran sehingga siswa dapat mempelajari pengetahuan dari model atau contoh yang dihadirkan guru. Dengan demikian, pemodelan merupakan asas penting dalam pembelajaran karena siswa dapat terhindar dari pengetahuan yang bersifat abstrak. Disamping itu karakteristik dari materi hidrokarbon sangat cocok dengan tahapan pemodelan ini. Hal tersebut dikarenakan karakteristik dari materi hidrokarbon yaitu konsep hidrokarbon sangat luas dan bersifat abstrak maka dari itu dengan adanya tahapan pemodelan ini siswa menjadi termotivasi dan lebih aktif dalam mengkontruksi atau membangun sendiri pengetahuannya.

Pada tahapan bertanya siswa diberikan kesempatan untuk mengidentifikasi masalah dengan cara membuat rumusan masalah berupa pertanyaan yang relevan dengan materi yang dipelajari. Kegiatan menanya dilakukan sebagai salah satu proses membangun pengetahuan siswa dalam bentuk fakta, konsep, prinsip, prosedur, hukum, dan teori. Tujuannya agar siswa memiliki kemampuan berpikir secara kritis, logis, dan sistematis (Kemendikbud, 2013). Kemudian siswa diberikan 
kesempatan untuk mencari informasi yang relevan dengan pertanyaan yang telah dirumuskan dari buku atau yang lainnya untuk merumuskan hipotesis. Siswa bekerja dalam kelompok untuk mendiskusikan hasil penyelidikan dari data yang terkumpul dan siswa diberikan kesempatan untuk merefleksi dan menyimpulkan materi yang dipelajari. Tahapan yang telah dilalui tersebut menyebabkan siswa menjadi aktif dan antusias dalam mengikuti proses pembelajaran sehingga hasil belajar siswa meningkat.

Tahapan yang menyebabkan meningkatnya hasil belajar siswa pada model pembelajaran kontekstual adalah tahap pemodelan, merumuskan pertanyaan, membuat hipotesis, serta melakukan penyelidikan dengan cara merancang suatu percobaan atau merancang suatu kegiatan pembelajaran. Pada proses pemodelan ini dalam penyampaian materi, konteks atau contoh yang dipilih harus sesuai dengan kehidupan sehari-hari dan tingkatan kognitif siswa. Pemilihan contoh yang sesuai dapat membantu siswa untuk berpikir dan mempertanggungjawabkan hasil tersebut (Setyawan \& Leonard, 2017). Selain itu pada tahapan ini siswa diajak untuk mengaitkan informasi yang ada dalam struktur kognitif siswa dengan pengetahuan baru yang diperoleh sehingga dihasilkan suatu pengetahuan utuh yang tidak mudah dilupakan (Ausubel dalam Ridho, 2011). Pada proses merumuskan pertanyaan dan membuat hipotesis, siswa mengumpulkan informasi dari membaca buku atau sumber lainnya sehingga siswa dapat menemukan penjelasan dari masalah yang dselidiki secara mandiri. Siswa menjadi lebih aktif dan terlibat dalam diskusi shingga semakin percaya diri untuk menyampaikan pendapat serta bertanya tentang hal-hal yang berhubungan dengan materi yang dipelajari. Seperti yang dikatan (Sabil, 2011) bahwa setelah mengalami pembelajaran dengan model pembelajaran kontekstual, siswa mengalami partisipasi aktif dalam berdiskusi, sehingga siswa berani untuk bertanya dan menyampaikan pendapatnya.Tahapan yang berkontribusi dalam meningkatkan hasil belajar siswa adalah tahapan inkuiri atau penyelidikan. Pada tahap inkuiri siswa dilatih berpikir pada aspek menganalisis, mengevaluasi, dan mengkreasi. Pembelajaran inkuiri akan mengasah siswa dalam memiliki kemampuan kritisnya dan mengembangkan penguasaan konsep melalui eksperimen (Kurniawati, et al, 2014). Pada tahap ini siswa diberikan kesempatan untuk merancang percobaan sehingga siswa ditantang untuk berpikir kritis untuk memecahkan masalah (Suardana, Redhana, Sudiatmika, \& Selamat, 2018).

Data yang telah terkumpul dianalisis oleh siswa secara berkelompok untuk memperoleh kesimpulan. Pada menganalisis dan mendiskusikan hasil dengan kelompok ini, siswa dilatih untuk mengaitkan informasi yang diperoleh dengan teori-teori yang sudah dimiliki siswa. Pengetahuan itu dibangun (dikonstruksi) sambil pebelajar mengatur pengalaman-pengalamannya yang terdiri atas struktur-struktur mental atau skemata-skemata yang sudah ada padanya (Suastra, 2004). Santiasi (2013) menemukan bahwa melalui mendiskusikan hasil percobaan dapat memberikan kesempatan kepada siswa untuk berpikir kritis. Pada tahapan kontruski ini juga, siswa membangun dan mengembangkan konsep yang diperoleh sehingga siswa dapat mengingat konsep yang siswa bangun sendiri atau pembelajaran menjadi bermakna. Proses pembelajaran yang bermakna dapat meningkatkan hasil belajar siswa.

Hasil penyelidikan atau diskusi yang dilakukan siswa dalam kelompok dikomunikasikan melalui sebuah presentasi di depan kelas. Hal tersebut bertujuan untuk memfokuskan pikiran siswa pada materi yang dibahas dan melatih kemampuan berkomunikasi siswa. Pada saat presentasi, siswa berperan aktif menyampaikan dan berdiskusi tentang hasil yang diperoleh dan guru berperan sebagai fasilitator memberikan arahan kepada siswa untuk menemukan jawaban. Siswa diberikan kesempatan untuk bertukar pikiran agar lebih memahami konsep-konsep pada materi yang dipelajari. Samani \& Hariyanto (2014) mengungkapkan bahwa melalui diskusi dapat menyadarkan siswa bahwa dengan berdiskusi mereka saling mengemukakan pendapat secara konstruktif sehingga dapat diperoleh keputusan yang lebih baik dan membiasakan siswa untuk berpikir kritis dan kreatif untuk mengungkapkan ide-idenya.

Setelah semua perwakilan kelompok menyampaikan hasil diskusi, siswa diberikan kesempatan untuk mengulas kembali materi yang telah dibahas sebelum siswa menyimpulkan pembelajaran yang telah dilakukan. Pada tahapan refleksi ini, guru menanyakan kembali tentang apaapa yang diperoleh siswa dari hasil pembelajaran dan memberikan penekanan pada konsep yang harus dikuasai siswa. Sanjaya (2008) mengatakan bahwa melalui proses refleksi pengalaman belajar itu akan dimasukkan dalam struktur kognitif siswa yang pada akhirnya menjadi bagian pengetahuan yang dimilikinya. Dengan demikian, dapat diketahui dengan melewati beberapa tahapan tersebut 
keterlibatan siswa selama proses pembelajaran dapat mempengaruhi hasil belajar siswa. Apabila siswa terlibat aktif selama proses pembelajaran maka hasil belajar siswa meningkat.

Efektivitas penerapan model pembelajaran kontekstual dalam meningkatkan hasil belajar kimia siswa juga didukung oleh aktivitas belajar siswa selama proses pembelajaran. Aktivits belajar siswa yang dibelajarkan dengan model pembelajaran kontekstual tergolong tinggi karena siswa terlibat secara langsung dalam kegiatan menemukan konsep selama proses pembelajaran. Hal ini dikarenakan pembelajaran kontekstual merupakan pembelajaran yang menekankan pada proses keterlibatan siswa secara penuh untuk menemukan materi yang dipelajari dan menghubungkannya dengan situasi kehidupan nyata (Taniredja, 2013). Aktivitas belajar siswa yang dibelajarkan dengan model pembelajaran kontekstual termasuk ke dalam kategori tinggi $(T)$ pada semua aspek sedangkan aktivitas belajar siswa yang dibelajarkan dengan model pembelajaran discovery termasuk ke dalam kategori cukup (C) pada 3 aspek dan tinggi $(\mathrm{T})$ pada 1 aspek.

Sementara itu, model pembelajaran discovery yang diterapkan di kelas kontrol dengan tahapan 1) menciptakan stimulus, 2) menyiapkan pertanyaan masalah, 3) mengumpulkan data, 4) mengolah data, 5) memverifikasi data, dan 6) menarik kesimpulan, belum mampu mengoptimalkan peran siswa secara aktif meskipun dalam proses pembelajaran dengan menerapkan diskusi kelompok dan diskusi kelas. Model pembelajaran discovery belum mampu mengoptimalkan peran siswa secara aktif karena siswa belum memahami beberapa tahapan dalam mengerjakan LKS yang mana siswa mengalami kesulitan mengidentifikasi masalah yang tercantum dalam teks fenomena yang diberikan. Pada model pembelajaran ini, siswa tidak secara langsung diberikan masalah dalam teks fenomena tersebut sehingga siswa harus mengidentifikasi masalah yang terdapat pada teks fenomena yang diberikan. Kesulitan dalam mengidentifikasi masalah berdampak pada tahapan selanjutnya yaitu dalam pembuatan hipotesis atau jawaban sementara dari masalah yang telah diidentifikasi. Siswa menjadi kurang antusias dalam mengikuti proses pembelajaran. Hal ini ditunjukkan melalui perilaku siswa yang kurang aktif untuk bertanya jika terdapat materi yang belum dimengerti dan siswa juga kurang aktif menjawab pertanyaan atau memiliki pendapat yang berbeda dengan kelompok penyaji. Berdasarkan beberapa masalah yang dihadapi di kelas kontrol yang menyebabkan proses pembelajaran di kelas control tidak berlangsung optimal. Hal ini mengakibatkan hasil belajar dan aktivitas belajar siswa di kelas control lebih rendah jika disbanding kan dengan hasil belajar dan aktivitas belajar siswa di kelas eksperimen. Menurut Ahmadi (2004), dalam kegiatan belajar anak golongan kreatif lebih mampu menemukan masalah dan mampu memecahkan masalah. Secara universal anak memiliki tingkat kreativitas yang berbeda-beda, ada yang memiliki tingkat kreativitas yang tinggi tetapi ada juga yang masih rendah. Kreativitas siswa mempunyai pengaruh yang cukup besar dengan menggunakan model pembelajaran discovery. Siswa yang memiliki kreativitas rendah akan mengalami kesulitan dalam proses pembelajaran dengan menggunakan model Pembelajaran discovery. Hal ini menyebabkan siswa yang memiliki kreativitas rendah mengalami kesulitan dalam memecahkan masalah terutama yang berkaitan dengan fenomena alam atau kehidupan sehari-hari dan materi yang bersifat abstrak sehingga hasil belajar siswa menjadi rendah (Agustina, 2016).

Berdasarkan pemaparan darimasing-masing model tersebut, dapat diketahui bahwa model pembelajaran kontekstual lebih dapat menuntun proses berpikir siswa dibandingkan dengan model pembelajaran discovery, karena pada model pembelajaran kontekstual menghadirkan konteks atau contoh nyata yang berhubungan dengan materi yang dipelajari sehingga dapat membantu siswa untuk berpikir dan mempertanggungjawabkanpikirannyatersebut. Olehkarenaitu, hasilbelajarsiswa yang dibelajarkandengan model pembelajaran kontekstual lebih baik dibandingkan hasil belajar siswa yang dibelajarkan dengan model pembelajaran discovery.

\section{SIMPULAN DAN SARAN}

Berdasarkan hasil penelitian yang telah diuraikan, dapat disimpulkan bahwa terdapat pengaruh signifikan model pembelajaran kontekstual terhadap hasil belajar kimia siswa. Hasil belajar siswa yang dibelajarkan dengan model pembelajaran kontekstual lebih tinggi dibandingkan dengan siswa yang dibelajarkan dengan model pembelajaran discovery.

Berdasarkan hasil-hasil yang telah dicapai, saran-saran yang dapat diajukan adalah model pembelajaran kontekstual dapat diterapkan oleh guru-guru di sekolah untuk meningkatkan hasil belajar siswa sehingga memperoleh hasil belajar yang maksimal, penerapan model pembelajaran kontekstual dapat dilakukan dengan melengkapi fasilitas pendukung, dapat dilakukan penelitian lebih lanjut 
dengan mengkaji topik berbeda sehingga diketahui konsistensi hasil penelitian ini, serta dapat diteliti hasil belajar pada ranah afektif dan psikomotor.

\section{DAFTAR PUSTAKA}

Agustina, W. 2016."Hubungan Hasil Belajardan Tingkat Berpikir Kreatif Siswa dalam Pembelajaran Matematika" Jurnal Pendidikan Matematika 2(3).

Ahmadi. A. 2004. Psikologi Pendidikan. Jakarta: RinekaCipta.

Ardiansyah, A. 2013."Meningkatkan Hasil Belajarpada Materi Pokok Hidrokarbon Melalui Model Pembelajaran Kooperatif Tipe TTW Bermuatan Karakter Siswa Kelas X-4 SMAN 6 Banjarmasin".Jurnal Inovasi Pendidikan Sains, 4(1):93-104.

Budiningsih, C. 2005. BelajardanPembelajaran. Jakarta: RinekaCipta.

Elvinawati. 2008. "Penerapan Pendekatan Kontekstual dalam Pembelajaran Kimia Sebagai Upaya Meningkatkan Aktivitas dan Hasil Belajar Siswa Kelas XI IPA 1 SMAN 1 Ketahun Bengkulu Utara". Jurnal Exacta, 2(6):17-22.

Kemendikbud. 2013. Permendikbud No 81A tentang Implementasi Kurikulum. Jakarta: Kementrian Pendidikan dan Kebudayaan.

Khutni, I.S., Maskur, danEmda, A. 2017. "Penerapan CTL dalam Meningkatkan Hasil Belajar Siswa Kelas X di SMAN 3 Timang Gajah pada Materi Hidrokarbon". Prosiding Seminar Nasional MIPA III (ISBN: 978-602-50939-0-6).

Maharani, L. 2013. "Pengaruh Model Pembelajaran Kontekstual Terhadap Penguasaan Konsep Koloid dan Sikapl Imiah Siswa". Jurnal Pendidikandan Pengajaran 46(1), 9-19.

Nurhidayati, E. 2016. Pengaruh Model Contextual Teaching and Learning (CTL) terhadap Hasil Belajar Siswa pada Materi Suhu dan Kalor Kelas XI di SMA Negeri 5 Banda Aceh.Skripsi (tidakditerbitkan).Fakultas MIPA, Universitas Islam NegeriAr-raniry Darussalam Banda Aceh.

Ridho, N. 2011. "Pembelajaran Bermakna". Tersedia pada http://skp.unair.ac.id/repository/Gurulndonesia/pembelajaranbermakn nurridho 10581.pdf. (diakses tanggal 17 Mei 2018).

Sabil, H. 2011. "Penerapan Pembelajaran Contextual Teaching and Learning (CTL) pada Materi Ruang Dimensi Tiga Menggunakan Model Pembelajaran Berdasarkan Masalah (MPBM) Mahasiswa Program Studi Pendidikan Matematika FKIP UNJA".Jurnal Pendidikandan Pengembangan Pendidikan. 1(1): 53-71.

Sanjaya, W. 2008.Strategi Pembelajaran Berorientasi standar Proses Pendidikan. Jakarta: Kencana Prenada Media Grup.

Santiasih, N.L., A.A.I.N., Marhaeni.,dan I.N, Tika. 2013. "Pengaruh Pembelajaran Inkuiri Terbimbing terhadap Sikapl Imiah dan Hasil Belajar IPA Siswa Kelas V SD No. 1 Kerobokan Kecamatan Kuta Utara KabupatenBadungTahunPelajaran 2013/2014". e-Journal Program PascasarjanaUniversitasPendidikanGanesha Program StudiPendidikanDasar(3).

Silaban, S., dan Debora. S. N. 2015. "Pengaruh Model Pembelajaran Contextual Teaching and Learning (CTL) terhadap Hasil Belajar Siswa pada Pokok Bahasan Sistem Koloid.Jurnal Pendidikan Kimia, 7.

Suardana, I N., Redhana, I W., Sudiatmika, A.A.I.A.R., danSelamat, I N. 2018. "Student's Critical Thinking Skills in Chemistry Learning Using Local Culture-Based 7E Learning Cycle Model". International Journal of Instruction 11(2): 400-412.

Suastra, I.W. 2004. Belajardan Pembelajaran Sains.Singaraja: IKIP N Singaraja. 
Vol. 3, No. 1, 2019

Suryanto, E., Susanti, E., danSaputro, S. 2015.“Efektivitas Model Pembelajaran Modified Free Inquiry (MFI) disertai Peer Tutoring terhadap Prestasi Belajar Siswa pada Materi Hidrolisis Garam Siswa Kelas XI Semester Genap SMA N 1 Kartasura Tahun Pelajaran 2013/2014".Jurnal Pendidikan Kimia (JPK), 4(2).

Taniredja, T. 2013. Model-Model Pembelajaran Inovatif dan Efektif. Bandung: Alfabeta

Perdana, D., Utomo, S. B., danYamtinah, S. 2014."Upaya Peningkatan Minatdan Prestasi Belajar Materi Hidrokarbon Melalui Penerapan Model Pembelajaran Kooperatif Tipe Student Team Achievement Division Berbantuan Kartu Soal pada Siswa Kelas X Semester Genap SMAN 8 Surakarta TahunPelajaran 2012/2013". Jurnal Pendidikan Kimia (JPK) 3(1).

Wartini, S. 2014. "Peningkatan Motivasi dan Hasil Belajar Kimia Hidrokarbon dengan Make a Match Siswa Kelas X SMA Negeri 2 Cepu Semester Genap Tahun 2012/2013". Jurnal Pendidikan Kimia (ISBN: 979363174-0) 